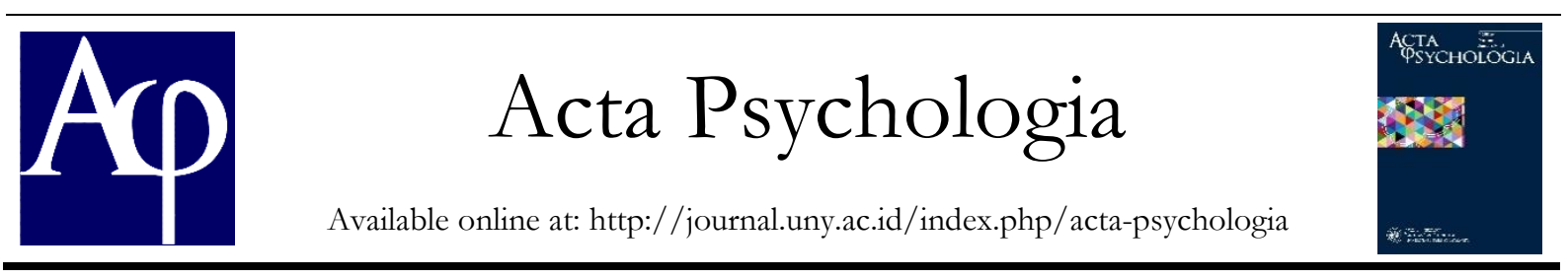

\title{
Konflik Peran Ganda dan Komitmen Polisi Wanita dalam Organisasi di Kepolisian Resor Kulon Progo
}

\author{
Valma Rahmasandy Agustin \\ Program Studi Psikologi, Universitas Negeri Yogyakarta; Jl. Colombo No. 1 Sleman Yogyakarta, \\ 55281 \\ valmarahmasandy@gmail.com
}

\begin{abstract}
Abstrak
Pada anggota polisi wanita yang telah berkeluarga, selain tugas dan tangggungjawab sebagai polisi juga mempunyai tugas dan tanggungjawab dalam keluarga.Tekanan, permintaan waktu dan harapan terhadap kedua peran tersebut menimbulkan konflik peran ganda.Penelitian ini bertujuan untuk mengetahui: (1) seberapa besar konflik peran ganda yang terjadi pada anggota polisi wanita; (2) seberapa besar komitmen anggota polisi wanita dalam organisasi; dan (3) apakah ada keterkaitan konflik peran dengan komitmen organisasi. Penelitian ini menggunakan kuantitatif ex-post facto. Sampel yang digunakan pada penelitian ini adalah mengambil seluruh populasi yang berjumlah 47 orang sebagai sampel, sehingga disebut penelitian populasi. Dalam penelitian ini menggunakan validitas isi dengan bantuan expert judgement. Hasil reliabilitas dimensi work family conflict adalah sebesar 0,659, dimensi family work conflict adalah sebesar 0,834, komitmen organisasi dimensi afektif adalah sebesar 0,950, komitmen organisasi dimensi kontinuans adalah sebesar 0,710, dan komitmen organisasi dimensi normatif adalah sebesar 0,387. Berdasarkan hasil analisis product moment, ditemukan bahwa: (1) work, family conflict berhubungan dengan komitmen afektif, dengan nilai $\mathrm{r}=-0,517$; (2) work family conflict berhubungan dengan komitmen kontinuans, dengan nilai $\mathrm{r}=-0,681$; (3) work family conflict berhubungan dengan komitmen normatif, dengan nilai $\mathrm{r}=-0,743$; (4) family work conflict berhubungan dengan komitmen afektif, dengan nilai $\mathrm{r}=-0,540$; (5) family work, conflict berhubungan dengan komitmen kontinuans, dengan nilai $r=-0,505$; (6) family work conflict berhubungan dengan komitmen normatif, dengan nilai $r=-0,402$. Sisimpulkan bahwa konflik peran ganda berhubungan dengan komitmen organisasi pada anggota polisi wanita di Kepolisian Resor Kulon Progo.
\end{abstract}

Kata Kunci: konflik peran ganda,komitmen organisasi, polisi wanita

\begin{abstract}
For female police officers who are married, in addition to their duties and responsibilities as a police officer, they also have duties and responsibilities within the family. Pressure, demand for time and expectations for both roles lead to dual role conflict. This research aims to find out: (1) how much conflicting dual roles happened to female police officers; (2) how big was the commitment of female police officers in the organization; and (3) whether there was a relationship between role conflict and organizational commitment. This study uses quantitative ex-post facto. The sample used in this study is to take the entire population of 47 people as a sample, so it is called population research. In this study using content validity with the help of expert judgment. The reliability results of the Dual Role Conflict dimension of work family conflict are 0.659, the Dual Role Conflict dimension of family work conflict is 0.834 , the organizational commitment of the affective dimension is 0.950 , the organizational commitment of the continuous dimension is 0.710 , and the organizational commitment of the normative dimension is 0.387 . Based on the results of the product moment analysis, it was found that: (1) work family conflict is related to affective commitment, with a value of $\mathrm{r}=-0.517$; (2) work family conflict is related to continuance commitment, with a value of $r=-0.681$; (3) work family conflict is related to normative commitment, with a value of $r=-0,743$; (4) family work conflict is related to affective commitment, with a value of $r=-0,540$; (5) family work conflict is related to continuance commitment, with a value of $r=-0.505$; (6) family work conflict is related to normative commitment, with a value of $r=-0,402$. It can be concluded that the dual role conflict is related to the organizational commitment of female police members in the Kulon Progo District Police.
\end{abstract}

Keywords: dual role conflict, organizational commitmen, women's police 


\section{Pendahuluan}

Pada dasarnya fungsi kepolisian adalah menjaga aturan-aturan yang telah ditetapkan untuk dipatuhi oleh warga Negara yang ada di wilayahnya. Untuk dapat melaksanakan fungsi tersebut, dibentuk badan atau lembaga atau organisasi yang disebut kepolisian pada setiap negara. Dalam perkembangan jaman yang semakin modern, Kepolisian Republik Indonesia atau biasa disingkat Polri tidak hanya mengurusi keamanan dan ketertiban saja, melainkan banyak tugas berat yang harus ditanggung oleh Polri sebagai organisasi mandiri.

Kepolisian di dalam Kamus Besar Bahasa Indonesia bermakna sebagai hal yang berkaitan dengan polisi. Pengertian polisi itu sendiri adalah badan pemerintahan yang bertugas memilihara keamanan dan ketertiban umum (menangkap orang melanggar undang-undang), serta diartikan sebagai anggota badan pemerintahan (pegawai negara yang bertugas menjaga keamanan) (KBBI, 2008). Kelana (1972) mengatakan bahwa istilah polisi memiliki dua arti. Pertama, polisi dalam arti formal yang mencakup organisasi dan kedudukan suatu instansi kepolisian. Kedua, polisi dalam arti material yang memberikan jawaban-jawaban terhadap persoalan tugas dan wewenang dalam menghadapi gangguan ketertiban dan keamanan berdasarkan peraturan perundangundangan.

Disamping sebagai pemelihara Keamanan dan Ketertiban Masyarakat (KAMTIBNAS), polisi juga sebagai aparat penegak hukum dalam proses peradilan pidana. Polisi adalah aparat penegak hukum jalanan yang langsung berhadapan dengan masyarakat dan penjahat (Rahardi, 2007).

Bekerja sebagai seorang polwan bukanlah tanpa masalah, Polisi wanita memiliki tugas, fungsi, visi misi dan tanggung jawab yang sama dengan polisi laki-laki, hal ini sudah dijelaskan dalam Undang-undang No. 2 Tahun 2002 tentang Kepolisian Negara Republik Indonesia.
Polisi wanita juga dituntut untuk menaati peraturan yang ada dalam organisasi Kepolisian, salah satu tentang jam kerja. Ketika ada kegiatan seperti operasi ketupat menjelang lebaran dan operasi lilin menjelang natal hampir seluruh personel kepolisian tanpa terkecuali diterjunkan langsung untuk mengatur lalu lintas dalam waktu 24 jam (Gitoyo, 2012). Hal ini terkadang menjadi pemicu timbul konflik peran, karena sebagian besar waktu dihabiskan dalam pekerjaan sehingga pihak keluarga yang merasa tidak nyaman menuntut untuk meluangkan waktu bersama keluarga.

Seorang polwan memiliki peran baik didalam pekerjaan maupun di keluarganya. Tuntutan antara pekerjaan dan keluarga tidak selalu sejalan sehingga dapat menimbulkan konflik peran.Konflik inilah yang mesti diperhatikan sebagai faktor pembentuk stres di tempat kerja, meskipun ada faktor diluar organisasi seharusnya organisasi juga memperhatikan hal ini. Karena pengaruh konflik peran terhadap kinerja polwan dalam organisasi Polri tersebut dan dapat berdampak pada pekerjaan yang dilakukannya. Konflik antara pekerjaan dan keluarga mempunyai pengaruh yang dapat menurunkan kualitas kehidupan rumah tangga dan keluarga serta mengganggu aktifitas pekerja (Kinnunen dan Mauno, 2008).

Seiring dengan perkembangan jaman dan dunia perindustrian, tentunya akan meningkatkan permintaan kebutuhan ketenaga kerjaan. Hal ini akan memberikan peluang yang lebih besar bagi siapapun untuk memasuki dunia kerja, termasuk wanita. Tidak heran jika sekarang ini semakin banyak wanita yang bekerja di sektor formal dan bersifat maskulinitas seperti ojek online, buruh bangunan, serta bekerja sebagai polisi yang biasa disebut dengan Polisi Wanita atau Polwan.

Greenhaus \& Beutell mendefinisikan konflik peran ganda sebagai suatu bentuk konflik antar peran dimana tekanan-tekanan dari pekerjaan dan 
keluarga tidak saling cocok satu sama lain. Seseorang akan menghabiskan waktu yang lebih untuk digunakan dalam memenuhi peran yang penting bagi mereka, oleh karena itu mereka bisa kekurangan waktu untuk peran yang lainnya. Hal ini bisa meningkatkan kesempatan seseorang untuk mengalami konflik peran.

Berprofesi sebagai polisi wanita lebih banyak dihadapkan pada tantangan, permasalahan dan kesulitan. Polisi wanita dituntut mengutamakan kepentingan dinas daripada kepentingan pribadi. Selain itu, polwan juga dituntut supaya patuh dan taat pada pimpinan, serta senantiasa melakukan perintah (Candi, 2001). Berkaitan dengan dinamika dan fenomena kerja polisi wanita yang memiliki peran ganda serta berbagai hambatan yang muncul sering kali menimbulkan konflik bagi polisi wanita. Permasalahan yang sering timbul pada wanita yang memiliki peran ganda adalah peran sebagai wanita dalam rumah tangga dan tetap membina karier.

Hasil survey dan wawancara studi kasus pada bulan Febuari 2019, yang dilakukan kepada anggota Kepolisian Resort Kulon Progo khususnya pada anggota Polisi Wanita yang sudah menikah. Studi kasus tersebut mengenai konflik peran ganda yang dihadapi oleh anggota polisi wanita. Mereka mengatakan adanya konflik peran antara peran dikeluarga dan peran sebagai polisi wanita terutama pada usia awal pernikahan. Banyaknya pekerjaan membuat kelelahan ketika sampai dirumah sehingga menyebabkan sedikitnya waktu bersama keluarga. Ketika diharuskan masuk kantor lebih cepat atau lebih awal merasa tidak maksimal dalam mengurus keluarga. Jadwal pekerjaan yang sering kali berubah, atau adanya perintah dari pimpinan membuat waktu bersama keluarga menjadi terganggu.

Tuntutan dan kewajiban yang harus dijalankan oleh seorang polisi wanita hal itu juga akan menimbulkan dampak pada psikisnya. Salah satu dampak secara psikis adalah rasa cemas ketika harus meninggalkan keluarga dalam melaksanakan pekerjaan. Sebagai anggota kepolisan, polisi wanita harus memiliki sikap tegas dan bijaksana jika harus dihadapkan dengan urusan pekerjaan dibandingkan dengan keluarga. Ketika salah satu anggota keluarga ada yang sakit membuat sulit untuk berkonsentrasi saat bekerja, sehingga keluarga sering mengeluh karena terlalu sibuk untuk bekerja.

Wanita yang bekerja juga mengalami masalah dalam komitmen mereka di dalam organisasi. Komitmen dalam organisasi merupakan keterlibatan individu dengan organisasinya yang dikarakteristikan dengan 3 faktor yaitu; 1) penerimaan dan kepercayaan akan tujuan dan nilai yang dianut organisasi, 2) kesediaan untuk menggunakan seluruh kemampuan guna kemajuan organisasi, dan 3) keinginan untuk tetap berada atau bekerja dalam organisasi (Panggabean, 2007: 135). Pada saat ada masalah keluarga mereka akan tetap bertahan pada organisasiatau tetap mengabdikan diri pada tujuan organisasinya atau mereka lebih memilih keluar dari pekerjaannya dan mengabdikan diri sepenuhnya untuk keluarga.

Sebagai seorang wanita karir seringkali memiliki peran ganda karena selain sebagai karyawan, polisi wanita juga memiliki peran di keluarga, dan lingkungannya. Peran-peran ini seringkali memunculkan konflik tuntutan dan konflik harapan. Adanya peran ganda pada profesi sebagai polisi wanita tentu memunculkan konflik peran dalam diri yang mempunyai dampak pada niat mereka untuk keluar dari perusahaan. Hasil penelitian yang dilakukan oleh Kusriyani, Magdalena, \& Paramita (2016) menunjukkan ada pengaruh signifikan dan negatif antara konflik peran terhadap komitmen organisasi. Hasil penelitian ini dikuatkan dengan penelitian yang dilakukan oleh Rageb, El-Salam, ElSamadicy \& Farid (2013) menunjukkan bahwa konflik peran berpengaruh negatif terhadap komitmen organisasi. 
Dari permasalahan di atas permasalahan yang ingin diteliti mengenai keterkaitan konflik peran baik dikeluarga maupun pada pekerjaan dan pengaruhnya terhadap komitmen dalam organisasi pada polisi wanita yang tentunya memiliki berbagai konflik peran. Tujuan dari penelitian ini adalah untuk mengetahui apakah ada hubungan konflik peran ganda dengan komitmen dalam organisasi pada anggota polisi wanita di Kepolisian Resor Kulon Progo. Penelitian ini diharapkan dapat memberikan manfaat di bidang psikologi yaitu mengenai konflik peran ganda dan komitmen dalam organisasi pada anggota polisi wanita di Kepolisian Resor Kulon Progo. Selain itu, penelitian ini diharapkan dapat memperkaya penelitian di bidang psikologi industri dan organisasi, sehingga hasil penelitian ini nantinya dapat dijadikan sebagai bahan penunjang penelitian lainnya yang berkaitan dengan Konflik Peran Ganda dan Komitmen dalam Organisasi. Serta dapat menjadi masukan dan informasi yang berkaitan dengan konflik peran ganda dan komitmen dalam organisasi pada anggota polisi wanita.

\section{Metode Penelitian}

\section{Jenis penelitian}

Penelitian ini merupakan penelitian ex-post facto, yaitu dilakukan saat setelah suatu kejadian itu terjadi. Metode penelitian ini bertujuan untuk menemukan penyebab yang memungkinkan perubahan perilaku, gejala, atau fenomena yang disebabkan oleh suatu peristiwa, perilaku, atau hal - hal yang menyebabkan perubahan pada variabel bebas secara keseluruhan sesudah terjadi (Sappaile,2010). Hubungan sebab-akibat tersebut didasarkan atas kajian teori yang menjelaskan bahwa munculnya suatu variabel disebabkan atau dilatarbelakangi oleh variabel tertentu.

\section{Waktu dan tempat penelitian}

Penelitian dilakukan di Kepolisian Resor Kulon Progo yang berfokus pada anggota polisi wanita di Kedungsari, Pengasih, Kabupaten Kulon Progo, Daerah Istimewa Yogyakarta. Waktu penelitian dilakukan sejak Februari 2019.

\section{Subjek Penelitian}

Penelitian ini merupakan penelitian populasi karena melibatkan satu populasi saja dengan subjek penelitian yaitu anggota polisi wanita di Kepolisian Resor Kulon Progo sebanyak 30 orang.

\section{Teknik pengumpulan data dan instrumen}

Teknik pengumpulan data dalam penelitian ini menggunakan kuesioner. Skala yang digunakan dalam penelitian ini mengadopsi dari ahli yaitu work-family conflict dan familywork conflict dari Greenhaus \& Beutell (1985) dan skala Komitmen Organisasi menggunakan aspek-aspek yang di kemukakan oleh Allen \& Meyer (1990). Aspek komitmen organisasi meliputi aspek afektif, aspek kontinuans, serta aspek normatif.

\section{Teknik Analisis data}

Teknik analisis data menggunakan Uji Korelasi Product Moment (Pearson). Uji Korelasi Product Moment bertujuan untuk menguji hipotesis asosiatif (uji hubungan) dua variabel.

\section{Hasil Penelitian dan Pembahasan}

\section{Karakteristik subjek}

Data hasil penelitian ini diperoleh melalui penyebaran skala psikologis yaitu skala Konflik Peran Ganda dan Komitmen Organisasi kepada anggota polisi wanita Kepolisian Resor Kulon Progo. Subjek yang terlibat dalam penelitian ini sebanyak 47 orang namun hanya 30 kuesioner yang kembali. Total item pada penelitian ini 
sebanyak 41 item yang terdiri dari 14 item dari Konflik Peran Ganda dan 27 item dari Komitmen Organisasi. Sebagian besar subjek berada pada rentang usia 21 sampai 30 tahun yakni sebanyak 21 orang dari total subjek. Pada tingkat pendidikan terakhir subjek adalah SMA/SMUyaitu berjumlah 14 orang total subjek. Lama bekerja sebagian besar subjek berada pada rentang $<10$ tahun yakni sebanyak 11 dari total subjek. Usia pernikahan sebagian besar subjek berada pada rentang $<10$ tahun yakni sebanyak 11 dari total subjek. Jumlah anak sebagian besar subjek berada pada rentang 1 yakni sebanyak 16 dari total subjek. Sebagian besar subjek juga memiliki ART yakni sebanyak 20 dari total subjek.

\section{Hasil data deskriptif}

Skor Konflik Peran Ganda (KPG) dimensi work family conflict dikategorikan dengan menggunakan rerata dan standar deviasi. Rerata yang diperoleh adalah 21 dan standar deviasi yang diperoleh adalah 4,6. Berdasarkan tabel di atas, dapat disimpulkan bahwa sebagian besar subjek memiliki KPG pada dimensi work family conflict yang sangat rendah yaitu sebanyak 18 orang atau $60 \%$. Hal ini memberi gambaran bahwa tingkat KPG dimensi work family conflict tergolong sangat rendah.

Tabel 1. Kategorisasi konflik peran ganda (KPG) dimensi work-family conflict dan family-work conflict

\begin{tabular}{lcc}
\hline Kategori & $\begin{array}{c}\text { Work- } \\
\text { family } \\
\text { conflict }\end{array}$ & $\begin{array}{c}\text { family- } \\
\text { work } \\
\text { conflict }\end{array}$ \\
\hline Sangat Tinggi & 0 & 0 \\
Tinggi & 1 & 1 \\
Sedang & 2 & 3 \\
Rendah & 9 & 4 \\
Sangat Rendah & 18 & 22 \\
\hline Total & $\mathbf{3 0}$ & $\mathbf{3 0}$ \\
\hline
\end{tabular}

Dari data KPG dimensi family-work conflict dikategori dengan menggunakan rerata 21 dan standar deviasi 4,6. Berdasarkan table tersebut dapat disimpulkan bahwa subjek memiliki KPG dimensi family-work conflict pada kategori sangat rendah, yaitu sebanyak 22 subjek atau $73,3 \%$. Hal ini memberi gambaran bahwa tingkat KPG dimensi family-work conflict tergolong sangat rendah.

Tabel 2. Kategorisasi komitmen organisasi dimensi afektif dan kontinuans

\begin{tabular}{cccc}
\hline Kategori & afektif & kontinuans & Normative \\
\hline Sangat & 0 & 0 & 0 \\
Tinggi & & & \\
Tinggi & 17 & 0 & 0 \\
Sedang & 5 & 0 & 16 \\
Rendah & 3 & 7 & 14 \\
Sangat & & & 0 \\
Rendah & 5 & 23 & \\
\hline Total & $\mathbf{3 0}$ & $\mathbf{3 0}$ & $\mathbf{3 0}$ \\
\hline
\end{tabular}

Data Komitmen Organisasi dimensi afektif dikategori dengan menggunakan rerata 36 dan standar deviasi 8. Disimpulkan bahwa subjek memiliki Komitmen Organisasi dimensi afektif pada kategori tinggi, yaitu sebanyak 17 subjek atau 56,7\%. Hal ini memberi gambaran bahwa tingkat komitmen afektif tergolong tinggi.

Data Komitmen Organisasi dimensi kontinuans dikategorisasikan menggunakan rerata 27 dan standar deviasi 6. Dapat disimpulkan bahwa subjek memiliki Komitmen Organisasi dimensi kontinuans pada kategori rendah, yaitu sebanyak 23 subjek atau 76,7. Hal ini memberi gambaran bahwa tingkat komitmen kontinuans tergolong sangat rendah.

Data Komitmen Organisasi dimensi normatif dikategori dengan menggunakan rerata 27 dan standar deviasi 6. Diketahui bahwa subjek memiliki Komitmen 
Organisasi dimensi normatif pada kategori sedang, yaitu sebanyak 16 subjek atau $53,3 \%$. Hal ini memberi gambaran bahwa tingkat komitmen normatif tergolong sedang.

\section{Hasil uji korelasi}

Berdasar uji korelasi product moment antara konflik peran ganda dan komitmen organisasi dengan SPSS for Windows 16, terdapat korelasi antara variabel dengan signifikansi $<0,05$. Ketentuan kuat dan lemahnya suatu hubungan menurut Pearson adalah 0,81-1,00 sempurna 0,61-0,80 kuat, 0,41-0,60 sedang, 0,21-0,40 lemah, dan 0,00-0,20 tidak ada. Korelasi product moment antara Work Family Conflict berhubungan dengan Komitmen Afektif sebesar -0,517. Korelasi antara Work Family Conflict berhubungan dengan Komitmen Kontinuans sebesar -0,681. Korelasi antara Work Family Conflict berhubungan dengan Komitmen sebesar -0,743. Korelasi antara Family Work Conflict berhubungan dengan Komitmen Afektif sebesar -0,540. Korelasi antara Family Work Conflict berhubungan dengan Komitmen Kontinuans sebesar -0,505. Kemudian korelasi antara Family Work Conflict berhubungan dengan Komitmen Normatif sebesar -0,402.

\section{Pembahasan}

Hasil dari penelitian ini menunjukkan bahwa terdapat hubungan negatif antara variabel konflik peran ganda dan komitmen organisasi. Artinya jika konflik peran ganda meningkat maka konflik peran ganda menurun, begitu pula sebaliknya. Konflik peran ganda dapat terjadi ketika anggota polisi wanita tidak mampu menyeimbangkan peran di organisasi dan peran di keluarga. Sehingga, hal tersebut dapat berpengaruh pada komitmen yang dimiliki pad anggota polisi wanita. Dalam hal ini anggota polisi wanita melakukan manajemen waktu untuk mengurangi konflik peran ganda yang dialami. Anggota polisi wanita yang dapat memanajemen waktu dengan dengan baik maka akan memiliki komitmen organisasi yang baik.

\section{Simpulan dan saran \\ Simpulan}

Berdasarkan hasil analisis penelitian yang telah dilakukan maka dapat ditarik kesimpulan bahwa variabel konflik peran ganda dan komitmen organisasi memiliki hubungan negatif. Pada anggota polisi wanita yang memiliki konflik peran ganda tinggi maka semakin rendah komitmen dalam organisasinya, begitu pula sebaliknya. Berdasarkan analisis maka hipotesis penelitian ini dapat diterima.

\section{Saran}

Berdasar hasil penelitian, peneliti mengajukan beberapa saran.

1. Instansi kepolisian dapat lebih memperhatikan keadaan anggota polisi wanita terutama yang sudah berkeluarga. Hal yang perlu diperhatikan yaitu penambahan penyediaan fasilitas ruang laktasi untuk ibu menyusui dan fasilitas penitipan anak seperti Taman Lalu Lintas. Hal ini bertujuan untuk membantu para anggota polisi wanita mendukung perannya dalam keluarga dan pekerjaan.

2. Pada anggota polisi wanita dapat meningkatkan kesadaran diri untuk dapat menyeimbangkan peran baik di dalam keluarga dan pekerjaan.

3. Bagi peneliti selanjutnya diharapkan dapat melakukan penelitian mengenai konflik peran ganda dengan menambah variabel lain. Hal ini karena hasil penelitian hubungan konflik peran ganda dan komitmen organisasi terdapat beberapa variabel lain yang mempengaruhi seperti stress kerja, kinerja, dan tingkat turnover. 


\section{Daftar Pustaka}

Achmadi, A.N.C. (2010). Metodologi penelitian. Jakarta: Bumi Aksara.

Amin, S.M \& Rozani A.H. (2014). Social support an a moderator to work family conflict and work family enrichment: A review. advanced review on scientific research, 2, 118.

Arikunto, S. (2010). Prosedur penelitian: Suatu pendekatan praktik. Jakarta: Rineka Cipta.

Azwar, S. (2018). Metode penelitian psikologi edisi III. Yogyakarta:Pustaka Pelajar.

Bambang, P \& Jannah, L.M. (2006). Metode penelitian kuantitatif: Teori dan aplikasi. Jakarta: PT Raja Grafindo.

Buhali, G.A. (2013). Pengaruh work-family conflict terhadap komitmen organisasi: Kepuasan kerja sebagai variabel mediasi. Jurnal Manajemen, 13(1).

Departemen Pendidikan Indonesia (2008). Kamus besar bahasa indonesia. Jakarta: Balai Pustaka.

Frone, M.R, \& Cooper, M.L. (1992). "Antecedents and outcomes of work-family conflick : Testing a model of the work-family interface". Journal of Applied Psychology, 77(1).

Gitoyo, Y. (2012). "Mengenal sejarah polisi wanita (polwan) di indonesia". Diunduh pada tanggal 28 Maret 2019 dari http://www.http://pustakadigitalI ndonesia.Blogspot.Com/012/09/ mengenal-sejarah-polisi-wanitapolwan.html.

Greenhaus, J., \& Beutell, N. (1985). Sources of conflict between work and family roles. Academy of Management Review, 10, 76-88.
Handayani, M. dkk. (2008). Psikologi keluarga. Surabaya: Fakultas Psikologi Universitas Surabaya.

Kinnunen , U. dkk (2004). Work-to-family conflict and its relationshipwith satisfaction and well-being: a oneyear longitudinal study on gender differences. Jurnal Internasional, $18,(11 / 22)$.

Melizawati. (2015). Pengaruh komitmen organisasi tehadap kinerja karyawan (stusi kasus pada pt. indonesia abadi). Jurnal Akuntasi,1(1), 15-16.

Meyer, J. P. \& Allen, N. J. (1991). A threecomponent conseptualization of organizational commitment. University of Western Ontario. Human Resource Management Review, 1(1), 61-89.

Meyer, J. P. dkk. (1993). Commitment organizations and occupation: Extension and test of a threecomponent conseptualization. University of Western Ontario. Journal of Applied Psychology, 74(4), 538-551.

Momo, K. (1972). Hukum kepolisian (perkembangan di Indonesia) Suatu Studi Histories Komperatif. Jakarta : Perguruan Tinggi Ilmu Kepolisian.

Netemeyer, R G, dkk. (1996). Development and validation of work family conflict and work. Journal Applied Psychology, 81(2).

Noor, J. (2011). Metodologi penelitian: Skripsi, tesis, disertasi, dan karya ilmiah. Jakarta: Kencana.

Panggabean, M. (2007). Manajemen sumber daya manusia. Bogor: Ghalia.

Pradita, A. C. (2016). Work-family conflict dengan komitmen organisasi pada karyawan. Skripsi. Universitas Muhammadiyah Malang.

Priyatnasari, N. \& Indar, B. (2013). Hubungan konflik peran ganda 
dengan kinerja perawat RSUD Kota Makassar. Skripsi. Universitas Hasanuddin.

Purwanto. (2008). Metodologi penelitian kuantitatif. Yogyakarta: Pustaka Pelajar.

Putri, B. S. (2017). Hubungan konflik peran ganda dengan stress kerja pada anggota kepolisian wanita. Skripsi. Universitas Muhammadiyah Malang.

Rahardi, P. (2007). Mengenal figur polisi kita. Yogyakarta : LaksBang Pressindo.

Riduwan. (2006). Metode dan teknik menyusun tesis. Bandung: Alfabeta.

Roboth, J.Y. (2015). "Work family conflict, stress kerja dan kineja wanita peran ganda pada yayasan compassion east Indonesia". Jurnal Riset Bisnis dan Manajemen, 3(1).

Rosita, S. (2012) . "Pengaruh konflik peran ganda dan stress kerja terhadap kinerja dosen wanita di fakultas ekonomi universitas jambi". Jurnal Manajemen Bisnis, 2(02).

Santrock, J.W. (2002). Life span development (edisi kelima). Jakarta: Erlangga.

Sari, R.W.P.M. (2016). Pengaruh konflik peran ganda dan stress kerja terhadap kinerja polisi wanita di polresta surakarta. Skripsi. Universitas Muhammadiyah Surakarta.

Sugiyono. (2012). Metode penelitian kuantitatif kualitatif dan red. Bandung: Alfabeta.

Susanto. (2009). "Analisis pengaruh konflik kerja-keluarga terhadap kepuasan kerja pengusaha wanita di kota semarang”. Jurnal Aset, 12(1). 7585.

Syah, M. (2004). Psikologi pendidikan. Bandung: PT Remaja Rosdakarya.
Undang-Undang Kepolisian Tahun (2002) Tentang kepolisisan negara republik Indonesia. Diunduh pada tanggal 20 November 2020. www.hukum.unsrat.ac.id.

Utama, D.G. dkk. (2015). Pengaruh workfamily conflict dan kepuasan kerja terhadap komitmen organisasional dan turnoverintention. Jurnal Manajemen, 4(11)

Widhiarso, W. (2010). Konstrak psikologis. Diakses pada 10 Juni 2020, dari http://wahyupsy.blog.ugm.ac.id/.

Wirakristama, R.C \& Suharnomo. (2011). Analisis konflik peran ganda (work-family conflict) terhadap kinerja karyawan wanita pada pt. nyonya meneer semarang dengan stress kerja sebagai variabel intervening. Skripsi. Universitas Diponegoro. 